\title{
Relationship between the arches of feet and the Cole's index
}

\author{
A - preparing concepts \\ B - formulating methods \\ $\mathrm{C}-$ conducting research \\ $\mathrm{D}$ - processing results \\ E - interpretation and \\ conclusions \\ F - editing the \\ final version \\ Marta Kinga Zdunek ${ }^{1, A-F}$, Małgorzata Lichota ${ }^{2, A-F}$, Krystyna Górniak, \\ 1Jozef Pilsudski University of Physical Education in Warsaw \\ ${ }^{2}$ Jozef Pilsudski University of Physical Education in Warsaw, \\ Branch in Biała Podlaska
}

https://doi.org/10.5114/areh.2019.85021

Key words: foot, child, physiotherapy, body weight

\section{Introduction}

The construction of the foot is characterized by a complex internal and external architecture of the skeletal system with longitudinal and transverse systems that support the weight of the human body. It allows the foot to adapt to variable ground conditions and is responsible for locomotion in various directions [1]. The skeletal system forming the foot arch, in performing its function, is supported by active ligaments and muscles, which constitute to its active stabilization. A properly constructed foot has three support points: the head of the I and $\mathrm{V}$ metatarsal bones and calcaneal bone [2].

In the period of development of body posture, the arching of the foot undergoes significant transformations. In infancy, the child's foot is provided with a fairly high content of fatty litter with a predominance of cartilage elements above the bones. The accumulation of the fat pad is mainly located within the longitudinal arch on the medial side of the foot, creating a distinct physiological 
flat foot. Longitudinal and transverse curves are not well marked. The foot is plastic due to the small progression of ossification processes and the undeveloped muscle and ligament system. Adaptation of the vertical position of the body by the child and the improvement of locomotive movements is the beginning of the formation of the longitudinal and transverse arches of the foot.

The most intensive development of feet relates to the preschool and early school age [3]. In 3-4-yearold children, the development of the plantar surface of the feet and characteristically fan-shaped and wide-set toes are observed, which provide more stable posture while walking; However, at the age of 4-5 there is a characteristic flattening of the foot, while at the age of 6-8 years the longitudinal arch is becoming quite clearly marked [4].

Postural and foot arches examinations are carried out in various regions of the Poland, indicating frequent occurrence of irregularities in the motor apparatus in children- mainly 30 to $60 \%$ [5-10]. Moreover, the number of children who are overweight and obese is increasing [11-13]. Body weight above the norm in childhood may be associated with metabolic, psychological and musculoskeletal disorders. It imposes functional restrictions on performing daily activities. It contributes to the reduction of the longitudinal and transverse arches, causing improper loading of the feet in terms of statics and dynamics [14-15].

Previous reports in the literature on the relationship between overweight and obesity, and flat feet have been consistent. For example, Pfeiffer et al. [16] demonstrated significant greater tendency for flat foot in girls and boys. Thirteen percent of the children were overweight or obese. Significant differences in prevalence of flat foot between overweight, obese, and normal-weight children were observed [16].

According to a report by the World Health Organization (WHO), about $10 \%$ of children and adolescents have an abnormal weight problem [17]. Particularly important is the prevention and treatment of emerging disorders in the early stages of development [18-20].

The aim of the work was to characterize the arch of the feet in children at the age of 5 and to look for the relationship between the quality of the arch of feet and the level of Cole's index.

\section{Material and Methods}

The research involved 44 five-year-old children. The average age of the group was $5.52(\mathrm{SD}=0.51)$. Girls constitute $43 \%$ (18), and boys- $57 \%$ (26) of all participants. The research was carried out in the Laboratory of Body Posture of the Regional Center for Research and Development of the AWF Branch in Biała Podlaska (Poland). The work is part of statutory research DS. 246 "Psychophysical condition of the 5 -year-olds children". The measurements were made by the doctor (rehabilitation) with many years of experience in the field of body posture correction and compensation. Parents (on behalf of their children) gave written consent for their children to participate in the study.

Body mass measurements with an accuracy of $0.1 \mathrm{~kg}$ and body height with an accuracy of $0.5 \mathrm{~cm}$, were made on a calibrated electronic scale (AIWIL equipment). The above parameters were used to calculate the Cole's index. Based on the criteria of this index, 90-109- normal values, 110-119- first degree obesity (overweight), 120-139- second degree obesity, 140 and above- grade III degree obesity and underweight in the range below 90\% were adopted [21-22]. The Cole's index is a newer indicator and the BMI is already obsolete.

The plantography method was used to examine the foot arches. The image of the plantar surface of the feet was scanned with the help of the CQ System Elektronik's podoscope (Poland). The assessment of the longitudinal arching of the feet was based on the Wejsflog index from 1955 [23]. The obtained results were referred to the criteria: normal foot (28-38), flat foot $\mathrm{I}^{\circ}$ (39-50), flat foot $\mathrm{II}^{\circ}$ (51-66), flat foot $\mathrm{III}^{\circ}$ (67100 ), flat foot $I V^{\circ}$ (above 100) and a hollow foot $(0-27)$.

The transverse arch of the foot was determined based on the length-width indicator. In the case of a correct transverse arch, the ratio of the foot length to its width should be $3: 1$, while the values closer to " 2 " indicate transverse flat foot [23].

In the assessment the front zone of support of the foot, the following items were considered: position of the big toe (angle $\alpha$ ), position of the small toe (angle $\beta$ ) and adjustment of the foot heel (angle $\gamma$ ). Standard value is set between 0 and 7 degrees. Values below the norm, both in the case of the big toe and the small toe, indicate the varus, values above the norm mean the valgus. The heel adjustment standard is $15^{\circ}-18^{\circ}$ [23]. The methodology for determining individual parameters of the foot is shown in Figure 1. 

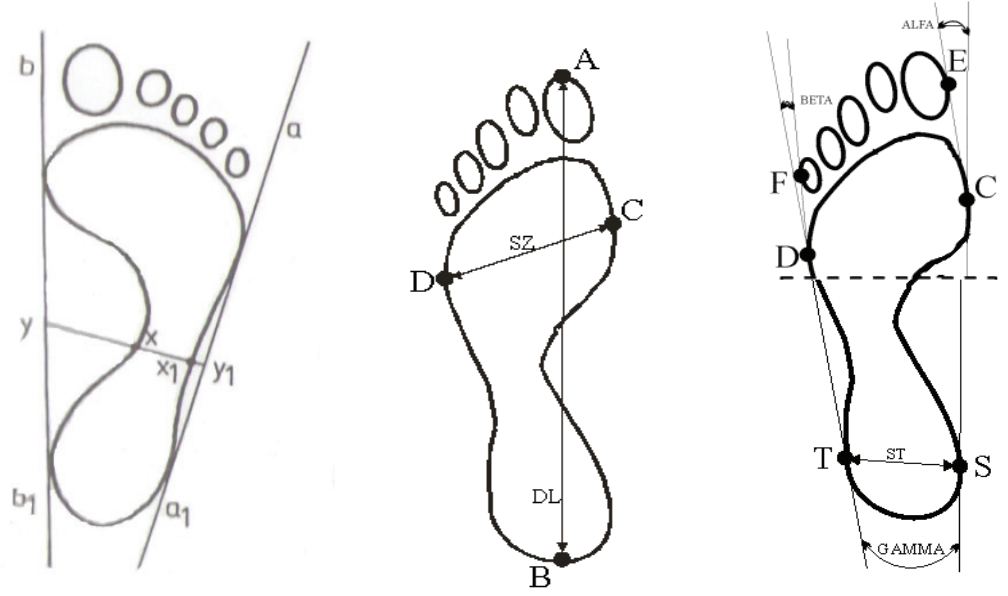

Fig. 1. Determination of the Wejsflog index, length-width indicator, angle $\alpha, \beta, \gamma$ [23]. [Wejsflog index $\left(|\mathrm{xx} 1| /|\mathrm{yy} 1|^{*} 100\right.$, length-width indicator $(|\mathrm{AB}| /|\mathrm{CD}|)$ ]

Criteria for inclusion in the study: 5 years of age, no orthopedic and neurological disorders, written consent of parents or legal guardians, properly performed image of the plantar surface of the feet. Exclusion criteria: age of the child below or above the accepted border, lack of consent of parents or guardians, occurrence of orthopedic or neurological disorders, incorrect image of the foot plantogram.

The following measures of descriptive statistics were used: arithmetic mean (M), standard deviation (SD) and minimum and maximum values (minmax). The severity and frequency of the occurrence of the arching of the feet was presented in \%. The Shapiro-Wilk test was used to check the normality of distributions of the analyzed variables. The Pearson correlation coefficient was calculated in order to check whether between the quotient variables whose distribution does not deviate from the normal, statistically significant correlations occur [24]. The value of $p<0.05$ was assumed as the level of significance. The statistical calculations were made in the IBM SPSS Statistics program.

\section{Results}

The analysis of collected research material shows that mean values of body weight, body height and Cole's index were higher in the group of girls than boys (Table 1). The mean values of the Cole's index indicated that the majority of five-yearolds were characterized by a normal body weight. Underweight was more common among boys (48.0\%), overweight (11.0\%) and obesity (16.0\%) among girls. Not observed statistically significant difference in body weight, body height and Cole's index between boys and girls.

Tab. 1. Mean values of body weight, body height and Cole's index of the examined children

\begin{tabular}{|c|c|c|c|c|c|c|c|}
\hline & \multicolumn{2}{|c|}{ Body weight $(\mathrm{kg})$} & \multicolumn{2}{c|}{ Body height $(\mathrm{cm})$} & \multicolumn{2}{c|}{ Cole's index $(\%)$} & $\mathrm{p}$ \\
\cline { 2 - 9 } & $\mathrm{M} \pm \mathrm{SD}$ & $\min -\max$ & $\mathrm{M} \pm \mathrm{SD}$ & $\min -\max$ & $\mathrm{M} \pm \mathrm{SD}$ & $\min -\max$ & $\mathrm{n} . \mathrm{s}$ \\
\hline+ & $21.5 \pm 3.8$ & $16.1-31.4$ & $116.4 \pm 5.3$ & $106.0-124.0$ & $105.8 \pm 14.9$ & $87.0-138.0$ & n.s \\
\hline$\delta$ & $20.7 \pm 2.8$ & $16.5-29.2$ & $115.8 \pm 5.8$ & $107.5-135.0$ & $90.9 \pm 8.0$ & $78.0-108.0$ & n.s \\
\hline
\end{tabular}

$*$ p $<0.05$; n.s. - no statistically significant differences

The longitudinal arching of the feet was analyzed based on the Wejsflog index, whose mean values were 44.8 (SD 25.18) in the left and right foot in girls, while in the boys group, 52.2 (SD 25.18) in the left foot and 57.8 (SD 19.03) in the right foot, indicating the occurence of flat foot (Figure $2)$. Differences between boys and girls were not statistically significant $(\mathrm{p}=0.236)$.
Correct longitudinal arching were found in $21.1 \%$ of the right foot and $10.5 \%$ of the left foot in girls and $12.0 \%$ and $16.0 \%$ respectively in the boys group. Taking into account the developmental characteristics of children at the age of five, $52.6 \%$ of girls and $36.0 \%$ of boys had correct course of the longitudinal arching in both feet. 
A distinct flattening of the longitudinal arching of the foot, flat foot $\mathrm{II}^{\circ}$, $\mathrm{III}^{\circ}$ and $\mathrm{IV}^{\circ}$ were observed in five-year-olds participants, more often in the left foot than the right foot. Three examined children had hollow foot (high-arched foot).
The mean values of the length-width indicator imply a decrease in the forward transverse arch in both girls and boys (Table 2). This situation was observed in $95 \%$ of girls and $92 \%$ of boys. More often correct transverse arch occurred in boys than in girls, both in the right foot $(16 \%)$ and left foot $(20 \%)$.

Tab. 2. Mean values of indicators defining longitudinal arching and transverse arch of the foot

\begin{tabular}{|c|c|c|c|c|}
\hline \multirow{2}{*}{} & \multicolumn{2}{|c|}{ Wejsflog index } & \multicolumn{2}{c|}{ Length-width indicator } \\
\cline { 2 - 5 } & Right foot & Left foot & Right foot & Left foot \\
\hline & $\mathrm{M} \pm \mathrm{SD}$ & $\mathrm{M} \pm \mathrm{SD}$ & $\mathrm{M} \pm \mathrm{SD}$ & $\mathrm{M} \pm \mathrm{SD}$ \\
\hline+ & $44.8 \pm 16.4$ & $57.8 \pm 19.2$ & $2.1 \pm 0.2$ & $2.1 \pm 0.1$ \\
\hline 0 & $52.3 \pm 20.1$ & $57.5 \pm 27.5$ & $2.1 \pm 0.3$ & $2.1 \pm 0.2$ \\
\hline
\end{tabular}

The mean values of the angle $\alpha$ in the right and left foot were higher, and in the case of angle $\beta$ and angle $\gamma$ slightly higher in the group of boys than girls. Correct position of the big toe (angle $\alpha$ ) was observed in over $50 \%$ of five-year-olds. In the group of boys, the big toe of the right foot was more often correctly set (over 57\%), while in the left foot girls (more than 50\%). The valgus of the big toe was more often observed in the left foot and the varus of the big toe in the right foot in both group.

The correct position of the small toe (angle $\beta$ ) was found more often in girls than in boys, both in the left and right foot. Over 3/4 five-year-olds had a valgus small toe, slightly more often in the left foot than in the right.

The heel was set correctly for most 5-year-olds (Table 3).

Tab. 3. Mean values of the angle of the big toe, small toe and heel of the examined children

\begin{tabular}{|c|c|c|}
\hline \multirow{2}{*}{} & Right foot & Angle $\alpha$ \\
\cline { 2 - 4 } & $\mathrm{M} \pm \mathrm{SD}$ & $\mathrm{M} \pm \mathrm{SD}$ \\
\hline$q$ & $1.3 \pm 5.7$ & $1.8 \pm 4.4$ \\
\hline$\hat{\sigma}$ & $2.6 \pm 6.0$ & $3.3 \pm 5.0$ \\
\hline \multicolumn{3}{|c|}{ Angle $\beta$} \\
\hline$q$ & $10.0 \pm 5.0$ & $9.1 \pm 4.6$ \\
\hline$\hat{\sigma}$ & $10.5 \pm 4.3$ & $10.3 \pm 4.0$ \\
\hline \multicolumn{3}{|c|}{ Angle $\gamma$} \\
\hline$q$ & $15.6 \pm 4.2$ & $16.3 \pm 2.3$ \\
\hline$\hat{\sigma}$ & $16.7 \pm 2.3$ & $16.9 \pm 1.9$ \\
\hline
\end{tabular}

In the group of boys with underweight and normal body weight, flat foot $\mathrm{I}^{\circ}, \mathrm{II}^{\circ}$ and $\mathrm{III}^{\circ}$ occurred more frequently. In girls with the normal body weight and overweight, they were generally flat foot: $\mathrm{I}^{\circ}$ and $\mathrm{II}^{\circ}$. In both groups, single cases of hollow foot were observed in each of the compartments according to the Cole's index.

In the group of girls, it was found that with the increase in the Cole's index, the values of the big toe (Angle $\gamma$ ) in the right foot increases, while the length-width indicator of the foot decreases (strong correlation). In the boys group, no statistically significant correlations were found between the Cole's index and the parameters studied. Details have been included in table 4. The results of the Shapiro-Wilk test are included in table 5.

Tab. 4. Correlations between the Cole's index and foot parameters among girls and boys

\begin{tabular}{|c|c|c|c|c|}
\hline & \multicolumn{2}{|c|}{ q } & \multicolumn{2}{|c|}{$\hat{\sigma}$} \\
\hline & \multicolumn{4}{|c|}{ Cole's index } \\
\hline & $\mathbf{R}$ & $\mathbf{p}$ & $\mathbf{R}$ & $\mathbf{p}$ \\
\hline Wejsflog index- left foot & 0.214 & 0.379 & -0.030 & 0.885 \\
\hline $\begin{array}{l}\text { Length-width indicator - } \\
\text { left foot }\end{array}$ & -0.250 & 0.302 & 0.150 & 0.474 \\
\hline Angle $\alpha-$ left foot & 0.284 & 0.239 & 0.299 & 0.147 \\
\hline Angle $\beta$ - left foot & 0.298 & 0.216 & 0.059 & 0.779 \\
\hline Angle $\gamma$ - left foot & 0.375 & 0.114 & 0.071 & 0.735 \\
\hline Wejsflog index- right foot & 0.374 & 0.115 & 0.084 & 0.689 \\
\hline $\begin{array}{l}\text { Length-width indicator- } \\
\text { right foot }\end{array}$ & -0.636 & $0.003 * *$ & -0.281 & 0.173 \\
\hline Angle $\alpha$ - right foot & 0.377 & 0.112 & 0.389 & 0.055 \\
\hline Angle $\beta$ - right foot & 0.121 & 0.621 & 0.027 & 0.897 \\
\hline Angle $\gamma$ - right foot & 0.525 & $0.021 *$ & 0.187 & 0.372 \\
\hline \multicolumn{5}{|c|}{$\begin{array}{l}\mathrm{R}-\text { Pearson correlation coefficient, } \mathrm{p} \text { - statistical significance, } \\
* \mathrm{p}<0.05, * * \mathrm{p}<0.01\end{array}$} \\
\hline
\end{tabular}

To conclude, in both sexes, there was no relationship between Cole's index and longitudinal arching, as well as small and big toe position in both foot. However, a correlation was found between the girls Cole's index and the transverse arch (lengthwidth indicator $)(\mathrm{p}=0.003)$ and the heel position (angle $\gamma)(\mathrm{p}=0.021)$ in the right foot. 
Tab. 5. Distributions of the analyzed variables

\begin{tabular}{|c|c|c|c|c|c|c|}
\hline & \multicolumn{3}{|c|}{ 우 } & \multicolumn{3}{|c|}{ 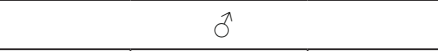 } \\
\hline & S-W & $\mathbf{n}$ & $\mathbf{p}$ & S-W & $\mathbf{n}$ & $\mathbf{p}$ \\
\hline & 0.924 & 19 & 0.134 & 0.951 & 25 & 0.262 \\
\hline Wejsflog index- left foot & 0.931 & 19 & 0.177 & 0.937 & 25 & 0.128 \\
\hline Length-width indicator - left foot & 0.937 & 19 & 0.232 & 0.898 & 25 & $0.017 *$ \\
\hline Angle $\alpha-$ left foot & 0.915 & 19 & 0.091 & 0.971 & 25 & 0.662 \\
\hline Angle $\beta$ - left foot & 0.972 & 19 & 0.813 & 0.963 & 25 & 0.477 \\
\hline Angle $\gamma$ - left foot & 0.889 & 19 & $0.031 *$ & 0.932 & 25 & 0.095 \\
\hline Wejsflog index- right foot & 0.939 & 19 & 0.249 & 0.957 & 25 & 0.353 \\
\hline Length-width indicator- right foot & 0.901 & 19 & 0.052 & 0.909 & 25 & $0.028 *$ \\
\hline Angle $\alpha$ - right foot & 0.933 & 19 & 0.196 & 0.981 & 25 & 0.909 \\
\hline Angle $\beta$ - right foot & 0.977 & 19 & 0.905 & 0.967 & 25 & 0.569 \\
\hline Angle $\gamma$ - right foot & 0.964 & 19 & 0.654 & 0.933 & 25 & 0.103 \\
\hline
\end{tabular}

\section{Discussion}

After careful analysis of the results, differences in somatic development of the five-year-olds studied were observed. Mean values of the body weight, body height were higher in the both study group. Differences were not statistically significant.

The similar observation conducted Pauk et al. [25], studying the influence of epidemiological factors on the occurrence of a flat foot in children. He also showed the increase in the Cole's index was accompanied by a decrease in the height of the foot arch in boys and girls. More often, the authors use the body mass index (BMI) to determine the body weight of the examined children for example, Jankowicz-Szymańska et al. [27] examining kindergarten children observed that boys were usually taller and had higher BMI values and weight than their own peers. Different results were obtained by Rzeźnik et al. [28] showing that a significant part of the examined children was overweight and obese, while $75 \%$ of boys and $81 \%$ of girls had normal somatic structure.

In the examined 5-year-olds, flat foot $\mathrm{I}^{\circ}, \mathrm{II}^{\circ}$, III $^{\circ}$ and hollow foot were found. Only 3 children had properly arched both feet. Similar results were obtained by Rzeźnik et al. [28], stating that the examined 5-6-year-olds had asymmetries in the longitudinal arching of the feet. Other results were received Trzcińska and Olszewska [29], examining a group of 447 children, showed a higher longitudinal arching in the right foot than the left in both sexes and Lichota and Górniak [30], when examining children from rural areas. It was noticed flat of the longitudinal arching in the both foot in girls and boys. This is also confirmed by the studies of Górniak, Lichota and Plandowska [31] conducted among five-year-olds.

In this study the analysis of the angle parameters of the arch of the feet shows the varus of the big toe in both feet was more common in girls, while the boys prevailed in the valgus of the small toe. Correct position of the heel was observed in $70 \%$ of girls and over $30 \%$ of boys. Similar parameters analyzed Lichota and Górniak [31] in the study of children observed correct positioning of the big toe and the heel. Gierasiewicz et al. [26], analyzing the body posture of urban children aged 3-6, noticed the correct position of the small toe and heel, and the values of the right big toe position were higher in boys more often than in girls. The author confirms only some of the observations.

This study examined the relationship between the Cole's index and the parameters of the arches of the foot, and statistically significant correlation was found only between the Cole's index and the transverse arch, and the heel position in the right foot in girls. Other conclusions are given in Walczak et al. [32]. Authors did not found any relationship between the foot and BMI. The same observation conducted also Puszczałowska-Lizis et al. [33] conducted studies showing longitudinal arching and transverse arch in children from younger school classes. It was found that in girls and boys, body weight is a feature that significantly affects the shape of the longitudinal arching of the foot, but does not affect lateral arching. Different results were obtained by Srokowska et al. [34], who did not observe a significant influence of the increased BMI 
on the occurrence of flat foot in pre-school children. The limited number of examined children may be a limitation of the study. It is worth investigating the relationship between the age of the examined children and the measured parameters.

\section{Conclusions}

Most of the examined children had normal body weight. Underweight was more frequent in boys, while overweight and obesity among girls. The correct arching of the right foot was more often found in girls, while the left foot in boys. Flat foot $\mathrm{I}^{\circ}, \mathrm{II}^{\circ}$ and $\mathrm{III}{ }^{\circ}$ were more often found in the boys group. A significant percentage of preschoolers examined had asymmetry in the longitudinal arching and transverse arch between right and left foot. Both groups showed a tendency to the varus of the big toe and valgus of the small toe, while the heel was positioned correctly in the majority of 5-year-olds. Foot arching and heel adjustment in the right foot. The position of the heel and transverse arch of the girls feet are probably influenced by body weight.

The introduction of an appropriate exercise program at pre-school age could reduce or remove postural defects and positively influence development of correct body posture, and therefore, reduce the risk of occurrence of health problems related to incorrect posture.

\section{References}

1. Lizis P. Kształtowanie się wysklepienia łuku podłużnego stopy i problemy korekcji płaskostopia u dzieci i młodzieży w wieku rozwojowym. Podręczniki i Skrypty nr 10, AWF: Kraków; 2004.

2. Demczuk-Włodarczyk E. Budowa stopy w okresie rozwoju progresywnego. Studia i Monografie, AWF: Poznań; 2003.

3. Wacławek P, Drzał-Grabiec J, Truszczyńska A. Rozwój stóp dzieci w wieku przedszkolnym. Adv Rehab. 2015;1:13-20.

4. Trzcińska D, Olszewska E. Cechy pantograficzne stóp dzieci i młodzieży w różnych okresach rozwojowych. Adv Rehab. 2006;20(1):47-53.

5. Latos-Bielenska A, Materna-Kiryluk A. Polish Registry of Congenital Malformation- aims and organization of the Registry monitoring 300000 births a year. JAG. 2005; 46: 341-348.

6. Kędra E. The Problem of Faulty Posture in Children and Adolescents of this Study. W: Seń M, Dębska G, redakcja. Zagrożenia zdrowotne wśród dzieci i młodzieży. Kraków. s. 57-70.

7. Jankowicz-Szymańska A, Nowak B, Słomski Ł. Parents knowledge about faulty postures. Physio. 2010; 18(2): 44-55.

8. Grzegorczyk M, Mroczek B, Grzegorczyk W, Karakiewicz B. The identification of postural defects in pre-school children. JPHNMR. 2014; 2: 25-29.

9. Makarczuk A. The level of school children's parent's knowledge about postural defects. J Health Sci. 2014; 4(13): $382-393$.

10. Maciałczyk-Paprocka K. Epidemiologia wad postawy u dzieci i młodzieży. UM w Poznaniu, praca doktorska, 2013: 88-89.

11. Mikoś M, Mikoś H, Obara-Moszyńska M, Niedziela M. Oberweight and obesity in children and adolescents. Now Lek. 2010; 79(5): 397-402.

12. Oblacińska A, Wrocławska M, Woynarowska B. Obesity among Polish adolescents: epidemiology, eating behaviours, dieting, physical acivity and well-being among overweight and obese adolescents. Pod Pol. 1997; 72: 241-245.

13. Krzyżaniak A. Zdrowie poznańskich uczniów. Wydawnictwo Miejskie: Poznań; 2009.

14. Mueller S, Carlson A, Mueller J, Baur H, Mayer F. Influence of obesity on foot loading *characteristics in gait for children aged 1 to 12 years. Gait \& Posture. 2016;11(2): 1-12.

15. Puszczałowska-Lizis E, Ciosek J. Foot shape and its relationship with somatic characteristic in pre-school children. 2017. Med Studies; 33(3): 214-221.

16. Pfeiffer M, Kotz R, Ledl T, Hauser G, Sluga M. Prevalence of flat foot in preschool-aged children. J Pediatr. 2006; 118(2):634-9.

17. Inchley J, Currie D, Jewell J, Breda J, Barnekow W. Observations from the Health Behaviourin School-aged Children (HBSC) WHO collaborative cross-national study. WHO. 2017: 1-68.

18. Decker A, Kołat N, Maksymowicz K, Krysa M, Heider R. Keep Straight- the Reasons for the Implementation and Description of Wroclaw Posture Prophylaxis. Piel. Zdr. Publ. 2013; 3(2): 175-181.

19. Jodkowska M, Oblacińska A, Mikiel-Kostyra K. Preliminary analysis of preventive care for infants, toddlers and preschool children-selected aspects. Prob Hig Epidemiol. 2009; 90(3): 347-354.

20. Radziminska R, Szyper S, Bulatowicz I, Srokowski G, Kazmierczak U, Strojek K. Prevention of Flat feet In preschool children. J Health Sci. 2012; 2(1): 25-39.

21. Cole TJ, Bellizzi MC, Flegal KM, Dietz WH. Ustalenia uniwersalnej definicji nadwagi i otyłości u dzieci na podstawie międzynarodowego badania przeglądowego. BMJ wydanie polskie. 2000; 24-28

22. Cole TJ. Body mass index cut offs define thinness in children and adolescents: international survey. BMJ. 2007; 335:194-201. 
23. Wejsflog G. Plantokonturografia. Polski Tygodnik Lekarski.1955; 10(52): 1670-1677.

24. Stupnicki R. Biometria. Krótki zarys. Wydawnictwo Margos: Warszawa; 2000.

25. Pauk J, Ezerskiy V, Rogalski M. Impact of epidemiological factors on occurrence of platypodia in children. J Physiother. 2010; 18(2): 21-27.

26. Gierasiewicz AN, Skiczinskaja AS. Dynamika wybranych wskaźników rozwoju fizycznego i stanu stóp u dzieci w wieku 3-6 lat. W: Wilczewski A, redakcja. Uwarunkowania rozwoju dzieci i młodzieży wiejskiej. Warszawa: WWFiS Biała Podlaska; 2010 .

27. Jankowicz-Szymańska A, Pociecha M. Zróżnicowanie wysklepienia podłużnego stóp u dzieci w wieku przedszkolnym. J Physiother. 2012; 2(20): 3-11.

28. Rzeźnik W, Lichota M, Baranowska D. Wysklepienie stóp dzieci w wieku przedszkolnym w rocznym okresie obserwacji. W: Jarosza W, Koprowiak E, redakcja.Kultura fizyczna a rozwój człowieka i społeczeństwa. Poznań: Studia i Monografie, AWF; 2013. s. $143-162$

29. Trzcińska D, Olszewska E. Cechy pantograficzne stóp 7-11-letnich uczniów. W: Górniak K., redakcja. Korektywa i kompensacja zaburzeń w rozwoju fizycznym dzieci i młodzieży. Warszawa: ZWWF Biała Podlaska; 2005. s. 90-101.

30. Lichota M, Górniak K. Wysklepienie stóp dzieci wiejskich. W: Sawczuk J., redakcja. Uwarunkowania rozwoju dzieci i młodzieży. Warszawa: ZWWF Biała Podlaska; 2006.s. 282-291.

31. Górniak K, Lichota M. Postawa ciała badanych dzieci. W: Kondycja psychofizyczna bialskich pięciolatków. Górniak K., redakcja. AWF Józefa Piłsudskiego w Warszawie, WWFiS w Białej Podlaskiej, 2017, s. 57-71.

32. Walczak M, Misterska E. Ocena wpływu wybranych parametrów morfologicznych na występowanie stopy płasko-koślawej u dzieci. Now Lek. 2008; 77: 343-346.

33. Puszcałowska-Lizis E, Ridan T, Ogarek M. Characteristic parameters of the longitudinal and transverse arch of feet in girls and boys in the early-school period. Young Sport Science of Ukraine. 2011; 3: 234-239.

34. Srokowska A, Piernicka D, Lewandowski A, Kowalik T, Siedlaczek M, Srokowski G, Radzimińska A. Overweight and flat feet in children of preschool age-research report. J Educ Health Sport. 2015; 5(4):380-404. 